\title{
A Case Study of Voluntary Disclosure by Chinese Enterprises
}

\author{
Desmond C.Y. Yuen (Corresponding author) \\ Faculty of Business Administration, University of Macau \\ Avenida Padre Tomás Pereira, Taipa, Macau, China \\ Tel: (853) 8397-4752Ｅ-mail: desmondy@umac.mo
}

Ming Liu

Faculty of Business Administration, University of Macau

Avenida Padre Tomás Pereira, Taipa, Macau, China

Tel: (853) 8397-4162Ｅ-mail: mliu@umac.mo

\section{Xu Zhang}

Faculty of Business Administration, University of Macau

Avenida Padre Tomás Pereira, Taipa, Macau, China

Tel: (853) 8397-4186 E-mail: xuzhang@umac.mo

\section{Chan $\mathrm{Lu}$}

Faculty of Business Administration, University of Macau

Avenida Padre Tomás Pereira, Taipa, Macau, China

Tel: (853) 8397-8500Ｅ-mail: luchan@umac.mo 


\begin{abstract}
This study examines the impact of ownership features, corporate governance mechanisms, and firm-specific characteristics on the voluntary disclosure provided by publicly-listed companies on the Shanghai Stock Exchange in China. The ownership structure features and corporate governance mechanisms include (1) concentration of ownership; (2) ownership by state and state-related institutions; (3) individual ownership; (4) the chief executive officer is also the chairman of the board of directors; (5) board independence, and (6) the existence of an audit committee. The firm-specific characteristics are (1) firm size; (2) leverage; (3) profitability, and; (4) type of industry. With the use of a relative disclosure index for measuring the voluntary disclosure level, our results indicate that individual ownership, the existence of an audit committee, firm size, and leverage, including board structure and functioning, employee information, director's remuneration, the presence of an audit committee, related party transactions, and stakeholders' interests, are significantly related to the extent of voluntary disclosure. This study provides empirical evidence for Chinese policy makers and regulators to improve corporate governance mechanisms and transparency of publicly-listed companies. The findings also contribute to an understanding of disclosure behavior among former wholly state-owned enterprises during the privatization process in China.
\end{abstract}

Keywords: Voluntary disclosure, Corporate governance, Audit committee, Disclosure index, Firm-specific characteristic

JEL Classifications: M40, M41, M48 


\section{Introduction}

The effective functioning of capital markets depends on how information is shared among the participants (Ho, 2003). In recent years, the quality of information disclosure in companies' annual reports has attracted considerable interest among scholars. Some companies disclose the information that is stipulated by local governance regulations, but there may be costs and benefits for disclosing additional financial information. By increasing the amount of information that companies release to the public, companies can lower their capital costs, gain investor confidence, and improve the marketability of shares (Meek et al., 1995; Kristandl and Bontis, 2007). According to a study by Ho and Wong (2001), the Asian financial crisis not only resulted from a loss of investor confidence but also from a lack of effective corporate governance and transparency in many of Asia's financial markets and individual firms in the late 1990s. The failures of Chinese companies, including Hongguang, Yorkpoint, Yinguangxia, Chaoda, Daqing Lianyi, CITIC, Zhengbaiwen, and Euro-Asia Agriculture, are examples of the results of operating under a weak corporate governance structure and a lack of transparency. The 2008 global financial crisis has led investors to pay more attention to additional disclosure of company information. Haw et al. (2000) note that firms listed on the two Chinese domestic stock exchanges, i.e., Shanghai and Shenzhen, disclose little information to the public. As a result, this study will investigate how the ownership structure and corporate governance mechanisms affect the level of voluntary disclosure of information by Chinese companies.

Compared to mature stock exchange markets in the developed countries, such as the United States and the United Kingdom, there are some unique features of the Chinese market. Since the 1980s China has been rapidly undergoing change from a traditional planned economy to a market economy. The privatization of state-owned enterprises (SOE) has transferred a portion of state-owned shares to other types of owners, including A, B, and $\mathrm{H}$ owners. Privatization encourages the injection of private capital into the SOEs. But it also transfers public assets to private agents who do not necessarily use the assets in effective ways (Stiglitz, 1997). The Chinese economic environment is different from that in the developed countries; the market economy is still at a developing stage and state ownership plays a leading, or even a controlling role in the public listing of companies. These unique characteristics lead to differences in corporate governance and the extent of disclosure of information by Chinese publicly-listed companies. The state's loss of control can result in ownership takeovers by individuals. Newman (2000) notes that takeovers are common; however, a rapid change of ownership may not improve firm transparency. In the cases of privatization in Eastern Europe and the former Soviet Union, many companies failed due to the lack of control and the expropriation of minority ownership. Because of agency effects, majority owners may reap personal benefits. As a result of the rapid changes in the stock market structure, Chinese regulatory bodies have published a list of laws and regulations for companies to eliminate the possibility of providing false information and to encourage voluntary disclosure so as to enhance their international reputations. Eventually, these policies will prepare the companies to list on foreign stock exchanges. The characteristics of corporate governance and the existence of an audit committee may affect the level of voluntary disclosure. Using an opacity 
index to indicate company' transparency, Kurtzman et al. (2004) show that the level of voluntary disclosure is affected by the legal system, government economic policy, accounting standards and governance rules, the regulatory structure of the financial system, and the business environment. If a company operates in an unstable environment, these high risk factors become part of its operational costs, thus making it difficult to predict the future. It will also slow down the company growth rate and performance. Other empirical studies have found that firms that have boards with a higher proportion of inside directors result in less management of earnings (Chtourou et al., 2001; Klein, 2002; Peasnell et al., 2001; Xie et al., 2001) and exhibit greater reporting conservatism (Beekes, Pope, and Young, 2002). Hence, it is hypothesized that a higher level of voluntary disclosure will lead to better performance and voluntary disclosure is a key way to improve investor confidence.

The main objective of this study is to test a set of corporate governance, ownership structure, and company characteristics that may affect voluntary disclosure practices. These characteristics include board structure and functioning, employee information, remuneration for the director, the presence of an audit committee, related party transactions, ownership information, and stakeholder interests. The variables include ownership concentration, government ownership, and related institutional ownership, individual ownership, dual roles of the CEO on the board of directors, the independence of the board of directors, and the existence of an audit committee. The characteristics of the ownership structure may affect the level of voluntary disclosure of information. The Chinese government has encouraged an increase in transparency so as to increase investor confidence in both the government and related institutional enterprises. One of the selling strategies for a company to increase the number of tradable shares to individual investors is to increase transparent reporting of information by enhancing the monitoring system through the creation of an audit committee, for the CEO not to play a dual role by also serving on the board of directors, and to improve the independence of the board directors. A well-governed firm will disclose more information to investors and creditors to enhance transparency and hence to improve company performance (Kurtzman et al., 2009). Diagram 1 indicates the framework of this study.

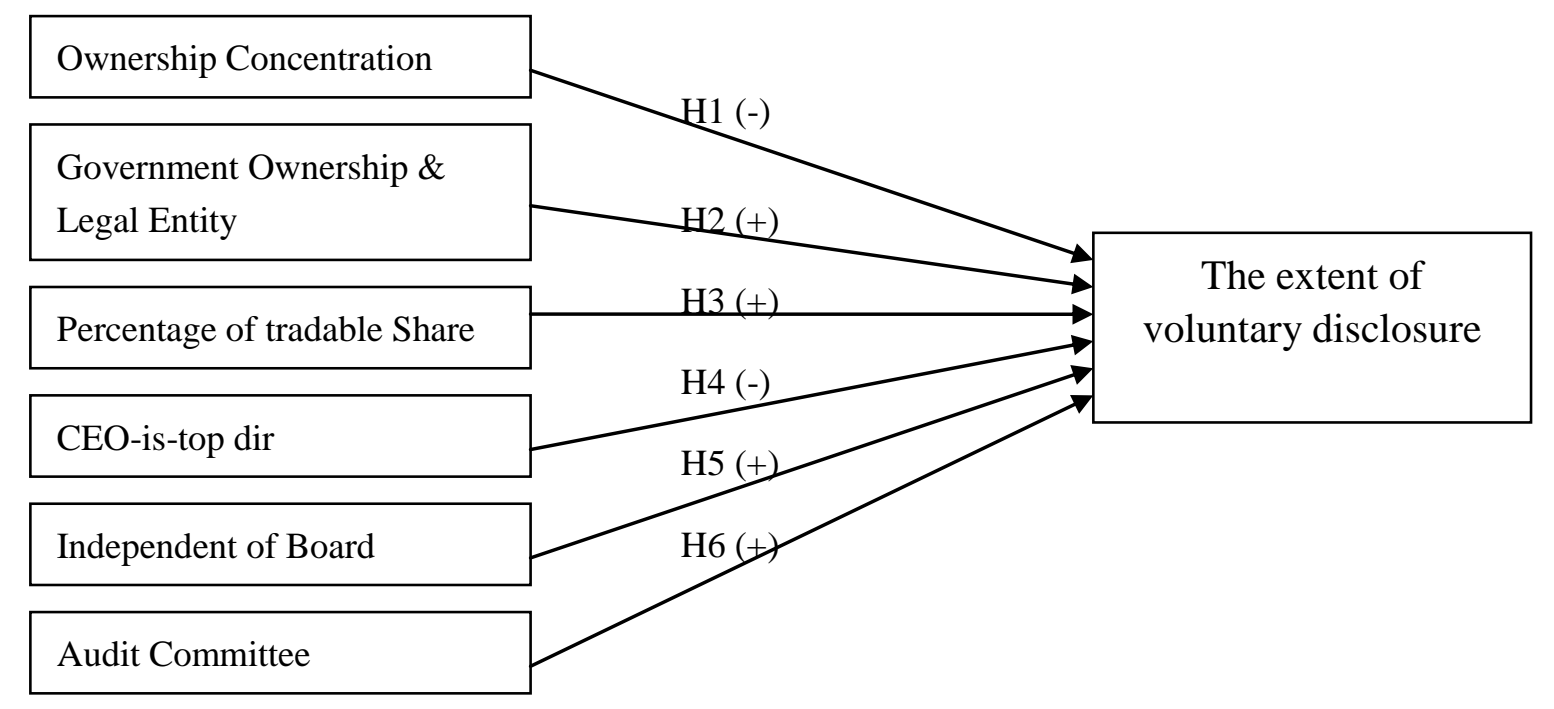

Control Variables: Firm Size, Leverage, Profitability, Industry Type 
Diagram 1 Research Framework

It is expected that this study will make several contributions. First, prior studies do not test the relationship between corporate governance and voluntary disclosure using Chinese financial and accounting data from the Shanghai Stock Exchange. This study attempts to provide empirical evidence for Chinese regulatory bodies and listed companies of the effectiveness of implementing voluntary monitoring systems. Second, prior studies (Ho and Wong, 2001) do not test the impact of a change in ownership structure on voluntary disclosure in China, thus leaving a research gap in the literature. Third, this study provides companies with evidence to further understand the most significant information that outside users seek to obtain from annual reports. A questionnaire containing 51 voluntary disclosure items was sent to financial analysts at the Bank of China. They were asked to score each item according to its importance. The results reveal 34 "most-important" items. This provides evidence for policy makers and regulators to encourage companies to provide more voluntary disclosures in their financial reports.

Section 2 introduces the literature on disclosure in China and presents the research framework and design. Section 3 discusses selection of the sample and formulation of the hypotheses. Section 4 presents the results of the multiple regression models. The final section summarizes the results and discusses the implications and limitations of the study.

\section{Mandatory vs. Voluntary Disclosure}

Both mandatory and voluntary disclosures are effective ways to release information to shareholders. A mandatory disclosure is a basic market demand for readers of the financial report; the readers must have access to this basic information as required by various laws and regulatory bodies in order to make company assessments. This requirement protects investors, and it also has indirect impacts on the corporate governance structure. A mandatory disclosure may help promote corporate governance by contributing to the effective exercise of shareholder franchises, by assisting shareholder enforcement of management fiduciary duties, and by raising managerial consciousness.

Casabona (2005) notes that global investors and creditors make their decisions based on information published in various non-financial, financial, and economic reports issued by listed companies. Investors and creditors also review the profitability, financial conditions, and non-financial conditions, such as employee information, the director's remuneration, and internal share transactions, before making investment decisions. Hence, voluntary disclosure, highly encouraged in Chinese companies, is an extension of the disclosure of the basic information that annual reports must contain, reflecting the economic realities of an entity in a meaningful, transparent, and comparable manner (Wong, 2008). Studies of voluntary disclosure have been conducted in many developed countries (Malone et al., 1993; Ling and Lundholm, 1996; Ferguson et al., 2002). In order to protect the interests of public investors and other market participants, an effective regulatory system of corporate disclosure is required. With the development of the securities market in China, many regulations relating to the public disclosure of information by listed companies have been promulgated. The 
specific regulations governing information disclosure of publicly-listed firms in China include provisional rules on the issuance of stocks and transaction management released by the State Council in April 1993. Standards governing the content and format of public disclosures by listed firms were promulgated in 1994 (and revised in 1998, 1999, 2001, 2002, 2003, 2004, and 2005). Notices on enhancing the quality of the disclosure of financial information by listed companies were released in 1999. Implementation guidelines (provisional) on information disclosure by companies making public stock offerings have been issued by the China Securities Regulatory Commission (CSRC).

Table 1 shows the specific accounting standards issued by the Ministry of Finance (MOF) and the listing rules in 2000 governing the Shanghai and Shenzhen Stock Exchanges. According to the regulations of the CSRC, a publicly-listed firm should publish the information in its entirety or schematic form in a CSRC-authorized national publication. In 1999 companies were concurrently required to publish summary printed annual reports and full reports on the Internet. The code of corporate governance released in 2001 further specifies that a publicly-listed company should provide the necessary information to its creditors so that the shareholders will have a better understanding of the company's operational and financial positions.

Table 1. Regulation Governing Financial Disclosures by Listed Companies in China

\begin{tabular}{|l|l|l|}
\hline \multicolumn{1}{|c|}{ Sources } & \multicolumn{1}{|c|}{ Items } & Effective date \\
\hline $\begin{array}{l}\text { Standing Committee, } \\
\text { National People's Congress }\end{array}$ & $\begin{array}{l}\text {-The Securities Law } \\
\text {-The Company Law }\end{array}$ & $\begin{array}{l}\text { 1 July } 1999 \\
1 \text { July } 1994\end{array}$ \\
\hline $\begin{array}{l}\text { State Securities Committee, } \\
\text { State Council }\end{array}$ & $\begin{array}{l}\text {-The Provisional Regulations on Stock } \\
\text { Issuance and Trading } \\
\text {-Provisional Measures on Prohibition of } \\
\text { Falsification in Securities Transactions }\end{array}$ & 22 April 1993 \\
\hline $\begin{array}{l}\text { China Securities } \\
\text { Supervisory Commission }\end{array}$ & $\begin{array}{l}\text {-Detailed Rules on Information Disclosures } \\
\text { by Publicly-Listed Companies } \\
\text {-Rules on the Content and Format of } \\
\text { Disclosure (Nos. 1-7) }\end{array}$ & 1993 \\
\hline Ministry of Finance & $\begin{array}{l}\text {-Accounting Standards for Business } 1993 \\
\text { Enterprises } \\
\text {-Accounting System for Stock Companies } \\
\text { (amended 1994 and 1998) } \\
\text {-Practical (Detailed) Accounting Standards } \\
\text { (thus far, nine standards have been } \\
\text { implemented) }\end{array}$ & Since 1995 \\
\hline Shanghai Stock Exchange & $\begin{array}{l}\text {-Guidelines on Information Disclosures by } \\
\text { Listed Companies } \\
\text {-Guidelines on the Operations of Listed } \\
\text { Companies }\end{array}$ & Since 1992 \\
\hline & Since 1990 1995 \\
\hline
\end{tabular}




\section{The Sample and the Survey}

Two types of shares are issued on the Shanghai Stock Exchange (SHSE) and the Shenzhen Stock Exchange: A-shares and B-shares. A-shares are mainly for domestic-market investors. $\mathrm{B}$-shares are for international market investors. Obviously, there are more companies issuing A-shares than B-shares. According to the CSRC, in 2003 there were 1,146 companies issuing A-shares and only 111 companies issuing B-shares. Because the A-share market accurately represents the situation in the Chinese securities market, this study selected a sample from the A-share market of the SHSE. Selection of the sample was based on the following criteria:

1. The percentage of selected sample firms is similar to that in the whole population;

2. The financial and insurance sectors are excluded from the final sample because such companies have different capital structures;

3. Companies with abnormal financial performance are excluded; and

4. Industries with less than five companies are eliminated.

The study randomly selected 200 companies from the Shanghai A-share market for the research sample. The industrial breakdown of the selected firms is presented in Table 2. The study has determined that there is no difference between the level of voluntary disclosure of manufacturing firms and non-manufacturing firms $(p>0.05)$. Therefore, the high proportion of manufacturing firms in the sample will not affect our interpretations of the results.

Table 2. Industry Breakdown of Selected Firms $(\mathrm{N}=200)$

\begin{tabular}{lcc}
\hline Industry Type & Number & Percentage \\
\hline Mining & 10 & $5 \%$ \\
Manufacturing & 118 & $59 \%$ \\
Utilities & 14 & $7 \%$ \\
Transportation and Warehousing & 18 & $9 \%$ \\
Information Technology & 16 & $8 \%$ \\
Wholesale and Retail Trade & 12 & $6 \%$ \\
Real Estate & 12 & $6 \%$ \\
& $\ldots \ldots \ldots \ldots \ldots$ \\
\hline
\end{tabular}

\subsection{Corporate Governance Characteristics}

This study focuses on the relationship between the extent of voluntary disclosure and corporate governance. It examines corporate governance from the perspective of the ownership structure, including (1) ownership concentration; (2) state-owned or related ownership; and (3) individual ownership. The controls for the directors and the audit committee include: (1) the independence of the non-executive directors; (2) the CEO as the 
top director; and (3) the existence of an audit committee. There are also controls for firm-specific characteristics, including (1) firm size; (2) leverage; (3) profitability; and (4) industry. Most of the data were collected from annual reports, which can be found on the Web site of the SHSE. Other data were collected from the China Stock Market and Accounting Research Database (CSMAR). The following includes information on the details and measurement of the data collection of the variables:

(i) Ownership concentration may expose higher potential agency problems (Jensen and Meckling, 1976). Ownership and management may generate benefits from entrepreneurial activities, such as the physical appointments of the office, pension funds, and personal benefits. Under a high (low) concentrated ownership structure, the managers' compensation is negatively (positively) related to company performance (Jiang et al., 2009; Ahman and Picur, 1997). The diverging interests between management and outside shareholders create an agency problem. In other words, firms with concentrated shareholdings should have greater control over minority shareholders. It is more efficient to monitor the compensation of managers in companies with a low level of ownership concentration. Controlling owners are likely to be less dependent on transparency and information disclosure (Erik and Anete, 2005), and they can obtain information directly from informal channels. Hence, a company with a centralized ownership structure will be reluctant to disclose additional information. Therefore, it is expected that there is a negative relationship between voluntary disclosure and ownership concentration. The following hypothesis is proposed:

\section{H1: There is a negative relationship between the extent of voluntary disclosure and ownership concentration.}

(ii) Government ownership, including ownership by government-related institutions (legal entities), of publicly-listed companies is a feature of the Chinese market. Some of the shares can only be transferred to domestic institutions with the approval of the CSRC. Most of the publicly-listed companies were originally held by SOEs and their shares are still controlled by the central or local governments. When they go public, the SOEs must transfer a high percentage of the shares to government bodies in order to preserve the socialist structure of the economy. There has been no prior research on voluntary disclosure and government ownership in the Chinese context. But Eng and Mak (2003) find that a company with significant government ownership in Singapore is associated with an increased propensity to disclose information. The government may have to consider the comprehensive development of the industry and the society. Jiang (2009), conducting a study of New Zealand companies, reaches a similar result -- a government- and management-controlled ownership structure has a considerably higher propensity to disclose more information. Agency costs are high in state-owned companies because of the conflicting objectives between the pure profit goals of commercial enterprises and goals related to national interests (Wong, 2008).

H2: There is a positive relationship between the extent of voluntary disclosure and government ownership.

(iii) Michael et al. (2002) find that firms with more tradable shares disclose significantly 
more strategic and financial information. Listed companies are required to meet listing requirements and to increase the level of transparency. Lauterbach and Vaninsky (1999) examine the effect of ownership structure on firm performance. They find that owner-managed firms are less efficient in generating net income and in disclosing information than firms managed by non-owners. This result suggests dispersed ownership and non-owner managers enhance firm performance and company transparency. The Chinese government requires that these companies disclose additional information before they can issue more shares to the public, thus allowing local investors to learn more about the firms' financial situation. The Chinese government can press publicly-listed firms to disclose more information by means of regulations and laws. From the company perspective, it must provide more information to potential investors in order to increase the attractiveness of its shares on the stock market (Meek et al., 1995). Therefore, the following hypothesis is proposed:

\section{H3: There is a positive relationship between the extent of voluntary disclosure and the percentage of tradable shares.}

(iv) The controlling power of the director means that the CEO is the key person in the company and he/she may also be the chairman or vice chairman of the board of directors (CEO duality). Chia et al. (2008) and Cheng and Courtenay (2006), in conducting empirical research in the United States, indicate that there is no significant relationship between CEO duality and company performance. Recently, an increased number of U.S. companies have converted from a dual to a non-dual CEO structure. But Chia et al. (2008) do not find any significant relationship between a non-dual structure and company performance. However, regulatory bodies and investors prefer a separation of the role of the CEO and chairman of the board of director. If such a dual role exists, the CEO may fail to play a monitoring role in the company. As noted by Bai (2003), the board of directors has a significant impact on company performance. The CEO's control of the board is expected to have a negative impact on company performance due to his/her excessive compensation. Under such conditions, a dual role is expected to contribute to ineffective monitoring. At the initial stage of a public offering, state owners prefer to retain a certain level of control and to assign the CEO to the board. This further indicates that with a change in ownership structure, firms may use inside directors to indirectly influence the company. This study provides empirical evidence of the relationship between corporate governance and its impact on the level of disclosure. The appointment of an independent board is one method to ensure alignment of the interests of the managers and owners. Hence, Ceo-is-top-dir is expected to have a negative impact on a company's voluntary disclosure. The fourth hypothesis can be presented as follows:

H4: There is a negative relationship between the extent of voluntary disclosure and the existence of CEO-is-top-dir.

(v) The percentage of outside (independent) executive members on the board of directors to the total number of directors appointed by the controlling shareholders represents the monitoring capacity of the company. It is expected that a high ratio shows that outside directors play a significant role in the company's monitoring system (Fama and Jensen, 1993; 
Rosenstein and Wyatt, 1990). Cheng and Courtenay (2006) examine the association between board monitoring and the level of voluntary disclosure. They find that firms with a higher proportion of independent directors on the board are associated with higher levels of voluntary disclosure. Although board size and CEO duality are not associated with voluntary disclosure, boards with a majority of independent directors have significantly higher levels of voluntary disclosure than firms with more balanced boards. The presence of an external governance mechanism, the regulatory environment, enhances the strength of the association between the proportion of independent directors and the level of voluntary disclosure. A company is expected to produce more voluntary disclosure when on the board there is a higher percentage of independent non-executive directors, who reduce the possibility of withholding information. Therefore, independent non-executive directors on the board have a positive relation with voluntary disclosure and performance. Good governance should protect and secure adequate returns for minority shareholders. According to Bai et al. (2003), a well-structured governance structure can be established by an independent board through transparent disclosure and by an effective legal environment which will reduce the tendency for dysfunctional behavior by the controlling shareholders. According to agency theory, the controlling shareholders may seek personal benefits rather than overall company success. The controlling shareholders may appoint the principal officers of the company. Hence, it is hypothesized that:

H5: High voluntary disclosure is expected when a company has a high percentage of independent non-executive directors on its board.

(vi) An audit committee can assist management boards and individual directors in the sharing of internal responsibilities. DeZoort and Salterio (2001) discuss the composition, functions, responsibilities, resources, and impacts of an audit committee on the corporate governance experience. To effectively fulfill its oversight functions, the audit committee should be independent, competent, financially literate, adequately resourced, and properly compensated. Forker (1992) argues that the existence of an audit committee improves the internal control system, thus it is one of the most effective monitoring mechanisms to improve the quality of disclosure. Generally, the duties of an audit committee include overseeing the quality of the financial information that is reported. The committee ensures that the management board is well informed about company decisions regarding accounting policies, practices, and disclosures. It also reviews the scope and outcomes of internal and external audits, and it oversees the financial reporting process (Wallace and Zinkin, 2005).

The effectiveness of an audit committee is dependent on several factors. The Earlier literature (Klein, 2002; Davidson et al., 2005) indicates that there is a relation between the independence of the audit committee and the effectiveness of corporate governance. According to Wallace and Zinkin (2005), the audit committee is likely to perform effectively when it is composed of a small group of between three and six members. Chtourou et al. (2001) and Xie et al. (2001) find that the committee is more effective when it participates in additional monitoring activities. The audit committee is an important mechanism to increase company transparency and to encourage management to disclose more information. We thus expect to find a positive relationship between the existence of an audit committee and the 
extent of voluntary disclosure. The following hypothesis is suggested:

H6: A positive relationship is expected between the extent of voluntary disclosure and the existence of an audit committee.

\subsection{Measurement of Voluntary Disclosure}

\subsubsection{Relative Disclosure Index}

There are three components to develop a measurement of voluntary disclosure by using the importance-adjusted relative disclosure index (RDI): (1) the items for voluntary disclosure; (2) the relative importance of disclosing an item of information; and (3) the extent of the actual disclosure of these items.

\section{(1) Items for Voluntary Disclosure}

The first step is to establish a voluntary corporate governance disclosure checklist. The checklist is developed with reference to several important corporate governance principles and recommendations by organizations, including the Organisation for Economic Co-operation and Development (OECD), the Australian Stock Exchange (ASX), the Hong Kong Securities Exchange (HKSE), and the CSRC. After reviewing the principles of these organizations, the principles were integrated into 120 items of corporate governance-related information and grouped in seven categories: 1) board structure and functioning; 2) employee-related issues; 3) director remuneration; 4) audit committee; 5) related party transactions; 6) controlling shareholders' interests; and 7) stakeholder interests.

All 120 disclosure items were checked to determine whether they are mandatory or voluntary items. In China, the 2002 code of corporate governance for listed companies and the no. 2 format and content of publicly-listed companies (revised in 2005) are the main mandatory disclosures required by the CSRC. After checking against these mandatory disclosure requirements, six categories and 51 items remained on the checklist; the remainder of the items were eliminated. The items are indicated in Table 3.

Table 3. Checklist of Voluntary Disclosure Items

\section{Voluntary Disclosure Items}

\section{Board Structure and Functioning}

1 Educational qualifications (academic and professional)

2 The skills and expertise relevant to the position of director held by each director holding the position at the time of the annual report

3 Directors' interests in competing businesses

4 Statement of directors' responsibilities regarding the financial statements

5 Statement indicating whether any bankruptcy has been filed by the company, its executive officers, or members of the board of directors within the previous ten years

6 The qualifications of the company secretary

7 The qualifications of the accountant 
$\begin{array}{ll}8 & \text { The full name and qualifications of the appointed compliance officer }\end{array}$

\section{Employees}

9 Details on the amount of employee remuneration, and remuneration policies, bonuses, and share option schemes

10 Amount spent on training

11 Nature of training

12 Policy regarding training

13 Categories of employees undergoing training

14 Number of employees trained

15 Welfare information (general)

16 Safety policy

17 Data on accidents

18 Cost of safety measures

19 Redundancy information (general)

20 Equal opportunity policy statement

21 Recruitment problems and related policies

22 Corporate culture development

\section{Directors' Remuneration}

23 How and by whom are the fees and other benefits of the non-executive directors determined

24 Analysis of the directors' remuneration - performance-based compensation

25 Analysis of the directors' remuneration - non-performance-based Compensation

26 The role and functions of the remuneration committee

27 Number of meetings per year

28 The names of the members of the remuneration committee

29 Attendance by committee members at committee meetings

30 Work undertaken by the remuneration committee during the year

31 Significant issues addressed during the year

32 The existence and terms of any schemes for retirement benefits other than statutory superannuation, for non-executive directors

\section{Audit Committee}

33 Details on the names and qualifications of those appointed to the audit committee

34 The role and function of the audit committee

35 Number of committee meetings 
36 Attendance at committee meetings

37 Statement of independence

38 Report on completed work

\section{Related Party Transactions}

39 Directors' current accounts/loans to officers

40 Directors' interests in significant contracts

41 A statement of the interests of each director and CEO of the company in equity or debt securities of the company or any associated corporation (class and number of such securities)

42 The details of any right to subscribe to equity or debt securities of the company granted to any director or CEO of the company or to the spouse or the children under the age of 18 of any such director or chief executive and the exercise of any such right

\section{Stakeholder Interests}

43 Company's acknowledgment of its wider social responsibilities, including environmental protection

44 Company's human resource policies, internal management structure, and workplace development initiatives

45 Commentary on the quality of the company's key relationships with investors, employees, customers, creditors, suppliers, and other significant parties

46 Company's contributions to the community

47 Social policy and value-added information

48 Environmental protection programs - qualitative

49 Environmental protection programs - quantitative

50 Charitable donations and activities

51 Community programs (general)

(2) The Relative Importance of Disclosing an Item of Information

After the checklist was established, a questionnaire containing 51 voluntary disclosure items were developed (refer to Table 4). Because this study focuses on A-shares that are traded domestically, local analysts were selected to determine the need of domestic investors for disclosure items. With the help of a senior-level manager of the Bank of China International, China (BOC) Ltd., questionnaires were sent to 100 internal financial analysts, 71 of whom responded via e-mail. Thus, the response rate was 71 percent. Among these 71 respondents, 5 refused to complete the questionnaire due to personal reasons or lack of time. Therefore, the remaining 66 respondents were used to develop the importance-adjusted relative disclosure index. The BOC analysts were asked to rate the importance of each item on a 7-point scale. After the questionnaires were returned, the average importance score of every voluntary disclosure item was calculated. The items with a minimum mean score of 4 remained on the 
checklist and the others were eliminated. The mean scores of 34 voluntary disclosure items were above 4 . Table 4 lists all the voluntary disclosure items and their average scores. The 34 voluntary disclosure items were then used to develop the importance-adjusted RDI.

Table 4. Disclosure Frequencies on the Voluntary Disclosure Index

\begin{tabular}{|c|c|c|}
\hline Disclosure Items & $\begin{array}{l}\text { Percentage } \\
\text { of total } \\
\text { responding } \\
\text { companies } \\
(N=66)\end{array}$ & $\begin{array}{l}\text { Average } \\
\text { Score }\end{array}$ \\
\hline Educational qualifications (academic and professional) & $28 \%$ & 4.6 \\
\hline $\begin{array}{l}\text { Skills and expertise relevant to the position of director held by } \\
\text { each director in position at the time of the annual report }\end{array}$ & $68 \%$ & 5.5 \\
\hline Directors interests in competing businesses & $5 \%$ & 6.4 \\
\hline $\begin{array}{l}\text { Statement of directors' responsibilities regarding the financial } \\
\text { statements }\end{array}$ & $100 \%$ & 5.8 \\
\hline Qualifications of the accountant & $16 \%$ & 5.6 \\
\hline $\begin{array}{l}\text { Details on the amount of employee remuneration, remuneration } \\
\text { policies, bonuses, and share option schemes }\end{array}$ & $10 \%$ & 4.6 \\
\hline Nature of training & $3 \%$ & 4 \\
\hline Training policy & $5 \%$ & 4 \\
\hline Categories of employees trained & $1 \%$ & 4.1 \\
\hline Safety policy & $3 \%$ & 4.5 \\
\hline Data on accidents & $1 \%$ & 4 \\
\hline Recruitment problems and related policies & $6 \%$ & 4 \\
\hline Corporate culture development & $6 \%$ & 4.8 \\
\hline $\begin{array}{l}\text { How and by whom are the fees and the other benefits of the } \\
\text { non-executive directors determined }\end{array}$ & $95 \%$ & 5.6 \\
\hline $\begin{array}{l}\text { Analysis of the directors' performance-based remuneration } \\
\text { compensation }\end{array}$ & $91 \%$ & 5.1 \\
\hline The role and functions of the remuneration committee & $8 \%$ & 5.3 \\
\hline Number of meetings per year & $4 \%$ & 4.1 \\
\hline The names of the members of the remuneration committee & $4 \%$ & 4.5 \\
\hline Attendance by committee members at committee meetings & $3 \%$ & 4.6 \\
\hline Work undertaken by the remuneration committee during the year & $4 \%$ & 4.8 \\
\hline Significant issues addressed during the year & $1 \%$ & 5 \\
\hline
\end{tabular}




\begin{tabular}{l}
\hline $\begin{array}{l}\text { Details on the names and qualifications of those appointed to the } \\
\text { audit committee }\end{array}$ \\
\begin{tabular}{l} 
The role and functions of the audit committee \\
\hline Number of committee meetings
\end{tabular} \\
\hline Attendance at committee meetings \\
\hline Statement on independence
\end{tabular}

(3) The Extent of Actual Disclosure of these Items

This process involved checking the annual reports of each company against the importance-adjusted relative disclosure items on the checklist. The total number of items for each company sample is disclosed. The actual disclosure of each company is reported in Table 4. The RDI of each sample company is computed as the ratio of the absolute disclosure score to the maximum possible disclosure score (Ho and Wong, 2001). The maximum possible disclosure score is the total number of items that the company disclosed in its annual report. The items considered irrelevant to the companies will not be disclosed. For example, because not all companies in the sample have an audit committee, such companies are not required to disclose the audit committee item.

\section{Measurement of the Independent Variables}

All the data were collected from the Chinese Stock Market and Accounting Research Database (CSMAR) and they were verified by the annual reports of the respective companies. The ownership of the 10 largest shareholders measures the ownership concentration, but some firms may have fewer than 10 shareholders (Haniffa and Cooke, 2002). Therefore, ownership concentration is measured in terms of a percentage. This variable is denoted as 
"Top10" The proportion of shares held by the government and related government institutions is published in the annual reports of the publicly-listed companies. In the Chinese market, government ownership includes the shares held directly by the government and the legal-entity shares that may be controlled by various government levels. These data can be retrieved from the companies' annual reports. They are measured in the form of a percentage to indicate how many shares the government holds. This variable is denoted as "PG." The proportion of individual shares (only A-shares) can also be collected from the annual reports of the listed companies. This variable is denoted as "TS." All the information about the directors of the publicly-listed companies is listed in their annual reports, including information about executive directors and independent non-executive directors. The proportion of independent non-executive directors (INDs) to the total number of directors is the number of independent non-executive directors on the board divided by the total number of directors on the board. The CEO-is-top-dir (CD) means that the same person is board chairman and CEO of the firm. The names of the board chairman and the CEO are available in the annual reports. The study codes a dummy variable that is equal to 1 if the board chairman and the CEO are the same, and 0 otherwise. Data on the existence of an audit committee (AC) use dummy variables to indicate its existence or non-existence, coded " 1 " or “ 0 ” respectively.

\subsection{Measurement of the Control Variables}

A regression model is used to test the relation between corporate governance and the voluntary disclosure items as stated in H1-H6 (see Table 7). First, it is necessary to control for company size. Hence, the natural logarithmic total sales $L N S$ as a control variable limits the possible size effects. Second, long-term debt/equity is used to control for possible leverage effects (Rajan and Zingales, 1995). Third, profitability (PROFIT) is measured by the return on equity. An average of three years of data was used to calculate profitability. Last, the industry type of every publicly-listed company can be found on the Web site of the SHSE. Table 2 indicates that there are seven industrial categories in this study.

\subsection{Descriptive Statistics and Bivariate Analysis}

Table 5 shows the distribution of the dependent variable $(R D I)$ and the mean of 0.2139 . The range is between 0.107 and 0.7058 . There is a large variation in the voluntary disclosure practices revealed in the annual reports of the Chinese publicly-listed companies. The disclosure frequency on the voluntary disclosure index and the average score were rated by financial analysts of the Bank of China. Only 5 items are disclosed in more than 50 percent of the sample and 25 items are disclosed in less than 10 percent of the sample. No sample company disclosed the "directors' current accounts/loans to officers and the directors' interests in significant contracts," which have the highest scores as rated by the financial analysts. The average score of all the voluntary disclosure items is 5.01, which is lower than the score reported in the study by Ho and Wong (2001) (their average score is 5.31). These results imply that publicly-listed companies in the Chinese market voluntarily disclose less information than the companies in Ho and Wong's Hong Kong sample. The low average score based on the analysts' ratings also indicates that they do not regard the annual reports as the most important source from which to obtain company information. The most important items obtained from the analysts are (1) the directors' interests in competing businesses; (2) the report on the completed work of the audit committee; (3) the directors' interests in 
significant contracts; (4) the statement of the interests (class and number of securities) of each director; and (5) the CEO's interests in the equity or debt securities of the company or any associated corporation.

The mean of the shares held by the top 10 shareholders is 66.95 percent (within a range of 35.5 percent to 90.59 percent). The mean ratio of shares held by the government is 33.39 percent (within a range of 0 percent to 76.51 percent). This result is consistent with the previous literature that shows that the ownership structure of publicly-listed companies on the Chinese stock market is highly concentrated and controlled by the state because these companies were originally SOEs. The mean ratio of independent non-executive directors is 34.55 percent (within a range of 20 percent to 44.44 percent). The descriptive statistics do not apply to the audit committee or the dominant personality variables because they are presented in the form of nominal variables.

Table 5. Summary Statistics of the Continuous Variables $(N=200)$

Mean Min. Max. Std.

\section{Dependent Variables}

$\begin{array}{llllll}\text { RDI } & \text { Extent of voluntary disclosures } & 0.214 & 0.107 & 0.706 & 0.095\end{array}$

\section{Independent Variables}

$\begin{array}{llllll}\text { Top10 The shares held by the top } 10 \text { shareholders } & 0.670 & 0.355 & 0.906 & 0.097\end{array}$

$\begin{array}{llllll}\text { PG The shares held by the government } & 0.340 & 0.000 & 0.765 & 0.239\end{array}$

$\begin{array}{lllllll}\text { INDs The ratio of independent non-executive } & 0.345 & 0.200 & 0.444 & 0.041\end{array}$ directors

LSIZE Firm size (measured by log of total assets)

$\begin{array}{llll}9.382 & 8.661 & 11.154 & 0.456\end{array}$

LEV Leverage ratio (total liabilities to total equity)

$\begin{array}{llll}0.496 & 0.138 & 0.802 & 0.154\end{array}$

PRF Profitability (measured by ROE)

$\begin{array}{llll}0.086 & -0.299 & 0.443 & 0.084\end{array}$

TS Tradable shares

$\begin{array}{llll}0.291 & 0.029 & 0.519 & 0.095\end{array}$

This study includes several nominal variables in the independent variables. The summary statistics of these variables are listed in Table 6. Among the publicly-listed firms, 52 percent have an established audit committee. The percentage of publicly-listed firms in which the CEO and the chairman of board is the same person is 17 percent. This means more companies are designed to establish audit committees and fewer companies have the management and ownership mix as reported by Ho and Wong (2000) (23.5 percent and 29 percent respectively).

Table 6. Summary Statistics of the Nominal Independent Variables $(N=200)$

\begin{tabular}{llc}
\hline Percentage of firms in the sample & \\
\hline AC & The existence of an audit committee & 52 \\
CD & The existence of CEO duality & 17 \\
IT & Industry types: Mining $\quad$ M & 5 \\
\hline
\end{tabular}




$\begin{array}{lc}\text { Manufacturing } & 59 \\ \text { Utilities } & 7 \\ \text { Transportation and Warehousing } & 9 \\ \text { Information Technology } & 8 \\ \text { Wholesale and Retail Trade } & 6 \\ \text { Real Estate } & 6\end{array}$

Table 7 shows the correlation matrix of all the dependent and independent variables. It is found that there are five variables that have a significant positive relationship with the RDI, including firm size, profitability, government and related institutions, percentage of independent directors on the board, and percentage of tradable shares held by individuals.

In contrast, the existence and leverage of an audit committee has a negative and significant sign to predict the RDI. The presence of the bivariate relationship further encourages interpretation of the results by multivariate analysis. All of the variables were put into multiple regressions to test their relationship with the dependent variable (RDI). A multicollinearity problem may exist in the multiple regression model and may affect the interpretations of the results. Therefore, a Variance Inflation Factor (VIF) was employed to test the presence of multicollinearity effects. The VIFs of all the independent variables are below 2, meaning that there is no multicollinearity in this multiple regression model. Table 8 shows the multiple regression results of the relationship between corporate governance and other specific characteristics on the extent of voluntary disclosure.

Table 7. Correlation Analysis

\begin{tabular}{lllllllll}
\hline & RDI & PG & INDs & LSIZE & LEV & PRF & TOP10 & TS \\
\hline RDI & 1.000 & & & & & & & \\
PG & $0.219^{* * *}$ & 1.000 & & & & & & \\
INDs & $0.185^{* *}$ & -0.048 & 1.000 & & & & & \\
LSIZE & $0.324 * * *$ & $0.292^{* * * *}$ & $0.161^{* *}$ & 1.000 & & & & \\
LEV & $-0.192^{* * *}$ & -0.029 & 0.061 & $0.206^{* * *}$ & 1.000 & & & \\
PRF & $0.159^{* *}$ & 0.081 & -0.057 & $0.212^{* * *}$ & -0.013 & 1.000 & & \\
TOP10 & 0.042 & $0.413 * * *$ & -0.046 & $0.180 * *$ & -0.003 & 0.021 & 1.000 & \\
TS & $0.130 *$ & $-0.215^{* * *}$ & $0.130 *$ & $-0.174 * *$ & -0.113 & $0.155^{* *}$ & $-0.602 * * *$ & 1.000 \\
\hline
\end{tabular}

$*$ significant at the $10 \%$ level, **significant at the 5\% level, and $* * *$ significant at the $1 \%$ level. $N=200$

Table 8. Multiple Regression Results of the Relationship between Corporate Governance and Other Specific Characteristics on the Extent of Voluntary Disclosure

$\mathrm{R}^{2}=0.374$

Adjusted $\mathrm{R}^{2}=0.313$

F Significance $=0.000$ 
Durbin - Watson Test $=1.991$

$\mathrm{N}=198$

\begin{tabular}{lcccc}
\hline Explanatory Variable & Coefficient & Std Error & Beta t-values & Significance \\
Constant & -0.484 & 0.265 & -1.829 & 0.069 \\
Top10 & 0.001 & 0.001 & 1.179 & 0.240 \\
PG & 0.039 & 0.027 & 1.470 & 0.143 \\
INDs & 0.374 & 0.152 & 2.470 & $0.015^{*}$ \\
LSIZE & 0.083 & 0.016 & 5.151 & $0.000^{*}$ \\
LEV & -0.175 & 0.041 & -4.315 & $0.000^{*}$ \\
PRF & -0.144 & 0.078 & -1.854 & 0.066 \\
TS & 0.292 & 0.095 & 3.070 & $0.003^{*}$ \\
CD & 0.011 & 0.015 & 0.722 & 0.471 \\
AC & -0.024 & 0.012 & -2.034 & $0.044^{*}$ \\
IT1 & -0.186 & 0.193 & -0.961 & 0.338 \\
IT2 & -0.215 & 0.157 & -1.373 & 0.172 \\
IT3 & -0.171 & 0.125 & -1.366 & 0.174 \\
IT4 & -0.061 & 0.091 & -0.671 & 0.504 \\
IT5 & -0.103 & 0.059 & -1.750 & 0.082 \\
IT6 & -0.035 & 0.034 & -1.023 & 0.308 \\
\hline
\end{tabular}

*Significant at the 5\% level.

Top10 $=$ The shares held by the top 10 shareholders.

$\mathrm{PG}=$ The shares held by the government.

INDs $=$ The ratio of independent non-executive directors.

LSIZE $=$ Firm size (measured by log of total assets).

LEV = Leverage.

PRF $=$ Profitability (measured by ROE).

$\mathrm{TS}=$ Tradable shares .

$\mathrm{CD}=$ The existence of CEO duality.

$\mathrm{AC}=$ The existence of an audit committee.

IT1 $=$ Industry type 1 .

IT2 = Industry type 2 .

IT3 = Industry type 3 .

IT4 = Industry type 4.

IT5 = Industry type 5 .

IT6 = Industry type 6 .

\subsection{Results and Discussion}

Based on the results in Table 8, Hypothesis 1 cannot be accepted. Hence, there is no relationship between voluntary disclosure and ownership concentration. Hypothesis 2 refers to a positive and significant $(p<0.1)$ relationship between the extent of voluntary disclosure 
and government or related institutional ownership. The results do not reject $H 2$. Both these results may be due to differences between the political direction of the Chinese government and the operations of listed companies. The Chinese government has encouraged the release of information so as to increase investor confidence and to improve China's international reputation. Government-controlled enterprises make preparations for listing internationally by providing financial transparency and disclosing adequate information disclosures on company operations to shareholders. It is expected that internationally listed companies will adopt international standards, will disclose sufficient information, and will follow international accounting standards to fulfill the requirements for overseas listings (therefore, $H 2$ is positive and significant). In practice, most of the large and controlling shareholders are appointed by government officials and they are reluctant to disclose information. Firm managers pursue their own interests rather than the interests of the shareholders, and there may be conflicts of interest between the controlling shareholders and other shareholders. La Porta et al. (1998) state that expropriation may be in the form of excessive compensation, loan guarantees, or transfer pricing between related companies.

An increase in the number of tradable shares has a significant and positive impact on the level of voluntary disclosure; hence hypothesis 3 cannot be rejected. Some companies may hope to increase the number of shares by selling to individual investors. But in order to attract more investors, they have to develop a good reputation. As a result, they will benefit from a lower cost of capital and they will be exposed to more investors. Thus, they are aware that they may benefit from greater disclosure.

The negative relationship between the extent of voluntary disclosure and the existence of CEO-is-top dir indicates that Hypothesis 4 cannot be supported. This finding is inconsistent with studies by Forker (1992) and Chen and Jeggi (1998). Only 17 percent of the companies have a CEO who is also chairman of the board, compared to 70-80 percent in the United States (Rechner and Dalton, 1991; Rhoades et al., 2001) and 54 percent in Hong Kong listed companies (Gul and Leung, 2004). The separation of ownership and management is emphasized in the transformation from state to private ownership. In recent years, state-owned companies have attempted to retain their influence over government-appointed CEOs. By doing so, company transparency is reduced. But some companies have succeeded in separating the two roles. Corporate transparency may be further improved by reducing the share of CEOs who are also chairmen of the board. Prevalent corporate governance practices in Europe separate the CEO and the chairman, and only 10 percent of UK publicly-listed companies combine the two (Coles et al., 2001; Higgs, 2003; Kang and Zardkoohi, 2005). These encouraging figures indicate that the separation of the two roles may contribute to the disclosure of more information.

Hypothesis 5 states that companies with a higher proportion of independent non- executive directors to total directors will be more likely to make more voluntary disclosures. This study supports H5. It also supports the studies by Fama and Jensen (1993) and Rosenstein and Wyatt (1990). There is more voluntary disclosure when there is a higher percentage of independent non-executive directors on the board who, in turn, reduce the possibility of withholding information. 
Hypothesis 6, stating that companies that have an audit committee are likely to have higher voluntary disclosure, is not supported. In fact, the opposite is found in a significant direction. This study does not find sufficient evidence to support Forker (1992) who finds a weak relationship and Ho and Wong (2001) who find a positive relationship between the two variables. The implication is that many companies in China voluntarily create audit committees to provide more effective communication between the board of directors and the external auditors. The audit committees are expected to oversee corporate governance, financial reporting, the internal control structure, internal audit functions, and external audit services. In China, the existence of an audit committee serves only to ensure that the company has complied with the mandatory disclosures. The purpose of the audit committee is not to press the company to disclose more voluntary information. The members of the audit committee may be appointed by the CEO or by the board of directors in order to fulfill shareholder requirements, and this may affect their monitoring roles in terms of their independence and trust. Thus, the audit committee may not increase company transparency or increase disclosure of non-mandatory information to the public.

\section{Implementation and Limitations of the Study}

This study examines the role of governance on issues of voluntary disclosure in China. For both Chinese regulatory bodies and listed companies, it is important to identify the corporate governance mechanisms that may affect company transparency. The privatization process of SOEs represents a gradual transfer of operational and financial control from state assets to individual investors. The speed of the transfer should be timed with progress in developing a strong regulatory governance system. In many countries with institutional weaknesses, such as China, regulatory capacity and reliability are limited. Yet this study concludes that in such environments, maintaining state control undermines the very important progress toward less direct state control. Most of the shares held by the government and legal entities in China are still concentrated (about 34 percent, see Table 5). This study reveals a relationship between the extent of voluntary disclosure and government ownership and ownership concentration. Since the 1990s, the Chinese government has introduced shareholding and publicly-listed companies have had to transfer their non-tradable shares to tradable shares, thus dispersing the ownership structure of publicly-listed companies to individual owners and potentially also affecting the level of voluntary disclosure.

This study also provides information on the expectations of both the investors and the creditors with respect to disclosure items. It finds that although more than half of the publicly-listed companies have audit committees, few companies disclose any information about their audit committees or their structures. But information on the audit committee is important so as to provide objective information to the readers of the annual reports. Therefore, management of publicly-listed companies should disclose more of this kind of information to fulfill the needs of the public. The regulatory body should provide some incentives to encourage companies to disclose more information. The current turmoil in financial markets presents audit committees (not only the audit committees of financial service companies) with the critical challenge of understanding how financial crises affect their risk profiles. From liquidity and access to capital, to fair value and asset impairment, and, ultimately, to the adequacy of the company's processes to manage these and other risks effectively, audit committees focus on the risks that companies face in the current environment. The audit committee should disclose these risks to the shareholders. 
After all, what are "institutions" if not governance mechanisms with some degree of autonomy from both political and private interests? The gradual creation of institutions that are partially autonomous from political power is central to the development of an optimal mode of regulatory governance. This study offers suggestions about providing maximum accountability in regulatory governance, in particular by creating an internal control system based on a rotating board, representing users, producers, and civic organizations, which is elected by a process involving frequent reporting and disclosure.

There are several major limitations to this study. First, it focuses only on the market in mainland China. The regulatory and economic situations in the China market are different from those of other markets. The results of this study only reflect characteristics of the China market. Therefore, future research should be extended to other markets. Given the impact of Chinese culture, high power distance and secrecy (Ailon, 2008; Hofstede 2005) may also have significant impacts on the level of disclosure. Because improvements in the corporate governance mechanism may change the management culture of Chinese companies, it is important to extend future studies to investigate how these issues may enhance transparency.

Second, the sample in this study is small, including only 200 companies of the 850 publicly-listed companies, and companies listed on the B-share market are not included. Furthermore, the study only examines the 2005 annual reports of the selected companies. Although the A-shares in the Shanghai and Shenzhen markets are quite similar, there are still some differences between them. For example, the Shanghai A-share market has more financial companies and the Shenzhen A-share market has more real estate companies. Therefore, the data may not precisely reflect the overall situation.

Third, due to resource limitations, it is difficult to increase the number of respondents, i.e., questionnaires to 100 analysts and 66 respondents. Our study bases the demands of users of annual reports for information on the opinions of only 66 financial analysts from the BOC to develop the RDI. Actually, the opinions of these 66 persons may not represent the opinions of all financial analysts in the China market. The generalizability of the findings may thus be limited. Future cross-country comparative studies are suggested to investigate the use of the RDI to measure the voluntary disclosure level in different countries.

Fourth, our study does not include other important independent variables that may also affect the extent of voluntary disclosure. Nazli and Pauline (2006) present other variables that affect the voluntary disclosure level of publicly-listed companies; for example, in the Malaysian securities market, companies with a higher ratio of family members on the board and a higher proportion of shares held by the executive directors disclose less voluntary information. Because information about family members on the board and the proportion of shares held by the executive directors is difficult to obtain, our study does not include these two variables. If additional resources are found, such information may be included in future research. The characteristics of the ownership structure, such as firms managed by professional managers, family members, partnerships of individuals, government or related entity ownership, can be considered to be moderating variables that may interact with the firm characteristics to affect the level of disclosure and company performance. It is suggested that future studies should address this issue. 


\section{Al Macrothink}

Finally, this study only analyzes one form of voluntary disclosure. It assumes that all disclosures are made in the form of the annual report which is the channel for public information. Thus, this study determines the actual extent of disclosure of publicly-listed companies based only on their annual reports. In practice, publicly-listed companies may release information in other forms as well. For example, they may release information through private meetings, the press, or interim reports.

\section{References}

Adams, M., \& Hossain, M. (1998). Managerial discretion and voluntary disclosure: Evidence from the New Zealand life insurance industry. Journal of Accounting and Public Policy. Vol.17, No.2, pp.245-281

Ahmed R., \& Picur, R. (1997). Performance Plan Adoption and Performance: The Contingency of Ownership Structure. Managerial Finance. Vol.17, Issue 5, pp.18-27

Ailon, G. (2008). Mirror, mirror on the wall: Culture's Consequences in a value test of its own design. The Academy of Management Review. Vol. 33, Issue: 4, pp. 885-904

Akerlof, G. (1970). The market for 'lemons': Quality uncertainty and the market mechanism. Quarterly Journal of Economics. Vol.84, No.3, pp.488-500

Alsaeed, K. (2006). The association between firm-specific characteristics and disclosure. Managerial Auditing Journal. Vol.21, No.5, pp.460-476

Amihud, Y., \& Mendelson, H. (1986). Asset pricing and the bid-ask spread. Journal of Financial Economics. Vol.17, No.3, pp.223-249

Bai, C., Liu, Q., Lu, J., Song, F.J., \& Zhang J. (2003). Corporate governance and market valuation in China. Journal of Comparative Economics. Vol.32, No.4, pp.599-616

Barako, D.G., Hancock, P., \& Izan, H.Y. (2006). Factors Influencing Voluntary Corporate Disclosure by Kenyan Companies, Corporate Governance. Vol.14, No.2, pp.309-324

Barth, M.E., \& Hutton, A.P. (2000). Information intermediaries and the pricing of accruals. Working Paper, Stanford University (Stanford, CA).

Beasley, M.S. (1996). An empirical analysis of the relation between the board of director composition and financial statement fraud. The Accounting Review. Vol.71, No.4, pp.443-465

Beekes, W., Pope, P., \& Young, S. (2002). The link between earnings conservatism and board composition: Evidence from the U.K. Working Paper, Lancaster University.

Beni Lauterbach B., \& Vaninsky, A. (1999). Ownership Structure and Firm Performance: Evidence from Israel. Journal of Management and Governance. Vol.3, issue 2, pp.189-201 


\section{Macrothink}

Berglöf , E., \& Pajuste, A. (2005). What do firms disclosure and why? Enforcing Corporate Governance and Transparency in Central and Eastern Europe. Oxford Review of Economics Policy.

Bradbury, M.E. (1992). Voluntary disclosure of financial segment data. Accounting and Finance. Vol.32, No.1, pp.15-26

Brown, L., Griffin, P., Hagerman, R., \& Zmijewski M. (1987). Security analyst superiority relative to univariate time-series models in forecasting quarterly earnings. Journal of Accounting and Economics. Vol.9, No.2, pp.61-87

Brown, L., \& Rozeff, M. (1978). The superiority of analyst forecasts as measures of expectations: Evidence from earnings. Journal of Finance. Vol.33, No.1, pp.1-16

Cha, L.M. (2001). The Future of China's Capital Markets and the Role of Corporate Governance. Luncheon Speech at China Business Summit, April 18, Vice Chairman, China Securities Regulatory Commission.

Cha, L.M. (2003). How to Implement the Modern Enterprise System of Listed Companies, Caijing Magazine. pp.46-47

Chau, G.K., \& Gray, S.J. (2002). Ownership structure and corporate voluntary disclosure in Hong Kong and Singapore. The International Journal of Accounting. Vol.37, No.5, pp.247-265

Chen, C.J.P., \& Jaggi, B. (2000). Association between independent non-executive directors, family control and financial disclosures in Hong Kong. Journal of Accounting and Public Policy. Vol.19, No.4, pp.285-310

Chen, D.H., Fan, J.P.H., \& Wong, T.J. (2003). Do Politician Jeopardize Professionalism? Decentralization and the Structure of Chinese Corporate Boards. Working Paper, Department of Accounting, Hong Kong University of Science and Technology.

Chen W.C., Lin J.B., \& Yi, B. (2008). CEO duality and firm performance - an endogenous issue. Corporate Ownership and Control. Vol. 6, Issue 1

Chen, Z., \& Xiong P. (2002). The illiquidity discount in China. Working paper, International Center for Financial Research, Yale University.

Cheng C.M., \& Courtenay S.M. (2006). Board composition, regulatory regime and voluntary disclosure. International Journal of Accounting. Vol.41, Issue 3, pp262-298

Chow, C., \& Wong, B.A. (1987). Voluntary Financial Disclosure by Mexican Corporations. The Accounting Review. Vol.62, No.3, pp.533-541

Chtourou, S.M., Bedard, J., \& Courteau, L. (2001). Corporate governance and earnings management. Working Paper, Universite Laval, Canada.

Clarkson, P., Guedes, J., \& Thompson, R. (1996). On the diversification, observability, and measurement of estimation risk. Journal of financial and quantitative analysis. Vol.31, No.1, 
pp.69-84

Clinch, G., \& Verrecchia, R.E. (1997). Competitive Disadvantage and Discretionary Disclosure in Industries. Australian Journal of Management.Vol.22, No.2, pp.125-138

Cooke, T.E. (1989). Voluntary corporate disclosure by Swedish companies. Journal of International Financial Management and Accounting. Vol.1, No.2, pp.113-123

Cooke, T.E. (1992). The impact of size, stock market listing, and industry type on disclosure in the annual reports of Japanese listed corporations. Accounting \& Business Research.Vol.22, No.87, pp.229-37

Davidson, R., Goodwin-Stewart, J., \& Kent, P. (2005). Internal governance structures and earnings management. Accounting and Finance. Vol.45, No.4, pp.241-267

Dechow, P.M., Sloan, R.G., \& Sweeney, A.P. (1996). Causes and consequences of earnings manipulation: An analysis of firms subject to enforcement actions by the sec. Contemporary Accounting Research. Vol.13, No.1, pp.1-36

Doe, J., \& Chan, W.Y. (2001). Towards Better Corporate Governance: China's Continuing Struggle. International Financial Law Review. Vol.9, No.1, pp.21-28

Eng, L.L., \& Mak, Y.T. (2003). Corporate governance and voluntary disclosure, Journal of Accounting and Public Policy. Vol.22, No.4, pp.325-345

Fama, E.F., \& Jensen, M.C. (1983). Separation of ownership and control, Journal of Law and Economics. Vol.26, No.2, pp.301-325

Fama, E.F., \& Miller, M. (1972). The Theory of Finance. New York, Hold, Rhinehart, and Winston.

Ferguson, M.J., Lam, C.K., \& Lee, M. (2002). Voluntary Disclosure by state-owned Enterprise listed on the Stock Exchange of Hong Kong. Journal of International Financial Management and Accounting. Vol.13, No.2: pp.171-192

Firth, M. (1979). The impact of size, stock market listing, and auditors on voluntary disclosure in corporate annual reports. Accounting and Business Research. Vol.9, No.33, pp.273-280

Forker, J.J. (1992). Corporate Governance and Disclosure Quaality. Accounting and Business Research. Vol.22, No.86, pp.111-124

Foster, G. (1986). Financial statement analysis. Englewood Cliffs, NJ: Prentice-Hall.

Francis, J., \& Soffer, L. (1997). The relative informativeness of analysts' stock 52 recommendations and earnings forecast revisions. Journal of Accounting Research. Vol.35, No.2, pp.193-212

Gerhard, K., \& Bontis, N. (2007). The impact of voluntary disclosure on the cost of equity capital estimates in a temporal setting. Journal of Intellectual Capital. Vol. 8 Issue 4, 
pp.577-594

Ghazali, N.A.M., \& Weetman, P. (2006). Perpetuating traditional influences: Voluntary disclosure in Malaysia following the economics crisis. Journal International Accounting Auditing \& Taxation. Vol.4, No.2, pp.226-248

Givoly, D., \& Lakonishok, J. (1979). The information content of financial analysts' forecasts of earnings: Some evidence on semi-strong efficiency. Journal of Accounting \& Economics. Vol.2, No.3, pp.165-186

Graham, J.R., Campbell, R., \& Rajgopal, S. (2005). The economic implications of corporate financial reporting. Journal of Accounting and Economics. Vol.40, No.1-3, pp.3-73

Haniffa, R.M., \& Cooke, T. E. (2002). Culture, Corporate Governance and Disclosure in Malaysian Corporations. Abacus. Vol.38, No.3, pp.317-349

Haw, I.M., Qi, D., \& Wu, W. (2000). Market Reaction to Earnings Announcements in an Emerging Capital Market: The case of China. Journal of International Financial Management and Accounting. Vol.11, No.2, pp.108-131

Healy, M., \& Palepu, K.G. (2000). A review of the empirical disclosure literature. Prepared for the $2000 \mathrm{JAE}$ Conference.

Ho, S.S.M., \& Wong, K.S. (2001). A study of the relationship between corporate governance structures and the extent of voluntary disclosure. Journal of International Accounting, Auditing \& Taxation. Vol.10, No.2, pp.139-157

Hofstede, G., \& Hofstede, J. (2005). Cultures and organizations: software of the mind . (Revised and expanded $2^{\text {nd }}$ ed). New York: McGraw-Hill.

Hossain, M., Tan, L.M., \& Adams, M. (1995). Voluntary Financial Disclosure by Australian Listed Companies. Australian Accounting Review. Vol.5, No.2, pp.33-50

Jensen, M.C., \& Meckling, W.H. (1976). Theory of the Firm: Managerial Behaviour, Agency Costs and Ownership Structure. Journal of Financial Economics. Vol.3, No.4, pp.305-60

Jiang, H. (2009). The impact of ownership concentration and voluntary disclosure practice in New Zealand. Accounting and Finance Association of Australia and New Zealand Conference Proceedings.

Jiang, H., Habib, A., \& Smallman C. (2009). The effect of ownership concentration on CEO compensation firm performance relationship in New Zealand. Pacific Accounting Review. Vol. 21, Issue 2, pp. 104-131

Klein, A. (2002). Audit committee, board of director characteristics, and earnings management. Journal of Accounting and Economics. Vol.33, No.3, pp.375-400

Kreps, D. (1992). A course in microeconomic theory. Princeton University Press, Princeton, NJ. 


\section{Al Macrothink}

Kristandl, G., \& Bontis, N. (2007). The impact of voluntary disclosure on cost of equity capital estimates in a temporal setting. Journal of Intellectual Capital. Vol. 8, Issue 4, pp. 577-594

Kurtzman, J., Yago, G., \& Phumiwasana, T. (2004). The opacity idex, research review, MIT Sloan Management Review.

Lang, M., \& Lundholm, R. (1993). Cross-sectional determinants of analyst ratings of corporate disclosures. Journal of Accounting Research. Vol.31, pp.246-271

Leftwich, R.W., Watts, R.L., \& Zimmerman, J.L. (1981). Voluntary corporate disclosure: the case of interim reporting. Journal of Accounting Research. Vol.19, No.4, pp.50-77

Lev, B. (1992). Information disclosure strategy. Calfornia Mangement Review. Vol.34, No.4, pp.9-32

Lin, T., \& Tang, Y.W. (2001). China's Securities Market and Accounting Disclosure Requirements: Current Problems and Suggested Solutions. Working paper, Leventhal School of Accounting, University of Southern California.

Lys, T., \& Sohn, S. (1990). The association between revisions of financial analysts' earnings forecasts and security price changes. Journal of Accounting \& Economics. Vol.13, No.3, pp.341-364

Mahmood, A. (1999). The impact of market characteristics on the comprehensiveness of disclosure in financial reports: an empirical study. The Journal of Commercial Researches. Vol.13, No.1, pp.47

Malone, D., Fries, C., \& Jones, T. (1993). An empirical investigation of the extent of corporate financial disclosure in the oil and gas Industry. Journal of Accounting, Auditing and Finance. Vol.8, No.3: pp.249-273

McNally, G.M., Eng, L.H., \& Hasseldine, C.R. (1982). Corporate financial reporting in New Zealand: An analysis of user preferences, corporate characteristics and disclosure practices for discretionary information. Accounting and Business Research. Vol.13, No.48, pp.11-20

Meek, G.K., Roberts, C., \& Gray, S.J. (1995). Factors Influencing Voluntary disclosure Annual Report Disclosures by U.S., U.K. and Continental European Multinational Corporations. Journal of International Business Studies. Vol.96, No.3, pp.555-572

Peasnell, K.V., Pope P.F., \& Young S.E. (2001). The characteristics of firms subject to adverse rulings by the financial reporting review panel. Accounting and Business Research. Vol. 31, issue 4, pp. 291-311

Prencipe, A. (2003). Proprietary costs and determinants of voluntary segment disclosure: Evidence from Italian listed companies. European Accounting Review. Vol.13, No.2, pp.319-340

Qi, D., Wu, W.Y., \& Zhang, H. (2000). Ownership structure and corporate performance of 


\section{Macrothink

partially privatized Chinese SOE firms. Pacific Basin Finance Journal. Vol.8, No.5, pp.587-610

Tenev, S., \& Zhang, C.L. (2002). Corporate Governance and Enterprise Reform in China. Washington: World Bank/IFC, pp. 1-104

Wallace, P., \& Zinkin, J. (2005). Corporate Governance, John Wiley \& Sons, February 1.

Wallace, R.S.O., Naser, K., \& Mora, A. (1994). The relationship between the comprehensiveness of corporate annual reports and firm characteristics in Spain. Accounting and Business Research. Vol.25, No.97, pp.41-53

Watts, R.L., \& Zimmerman, J. L. (1978). Towards a positive theory of the determination of the accounting standards. The Accounting Review. Vol.53, No.1, pp.112-134

Xiao, Z. (1999). Corporate Disclosure made by Chinese Listed Companies, The International Journal of Accounting. Vol.34, pp.349-373

Xie, B., Davidson III, W.N., \& DaDalt, P.J. (2001). Earnings management and corporate governance: The roles of the board and the audit committee. Working paper, Southern Illinois University.

Xie, B., Davidson, W.N., \& DaDalt, P.J. (2001). Earnings management and corporate governance: the roles of the board and the audit committee, Working paper (Southern Illinois University, Carbondale, IL).

Xu, X.N., \& Wang, Y. (1999). Ownership Structure and Corporate Governance in Chinese Stock Companies. China Economic Review. Vol.10, No.1, pp.75-98

Zhang, W.Y. (1999). Property Right, Corporate Governance and Performance: An Evaluation on China's SOE (in Chinese), Shanghai Fareast Publishing House. 